\title{
PENGADMINISTRASIAN PENYERTAAN MODAL DAERAH KEPADA PERUSAHAAN DAERAH AIR MINUM SEBAGAI TANGGUNG JAWAB DALAM MENSEJAHTARAKAN RAKYAT
}

\author{
Teuku Ahmad Yani
}

Fakultas Ilmu Sosial dan Ilmu Politik, Uiversitas Teuku Umar

\begin{abstract}
The state of pancasila as a welfare state put the state to participate berpatisipasi in the service of drinking water for its citizens. The existence of capital participation by an area on regional water company was owed juridical who must be done. Capital participation need orderly adminstrasi in rangkan upholds accountability in financial administration the state, especially regional financial.
\end{abstract}

Keywords: Equity, Regions, Local Drinking Water Company 


\section{PENDAHULUAN}

Negara Indonesia menurut Undang-Undang Dasar Negara Indonesia Tahun 1945 (UUD) adalah negara hukum. Oleh karena itu setiap tindakan negara harus sesuai dengan aturan hukum. Undang-Undang Nomor 12 Tahun 2011 Tentang Pembentukan Perundang-Undangan menegaskan bahwa aturan hukum itu memiliki jenjang, dimana UUD memiliki kedudukan yang lebih tinggi, sehingga harus menjadi rujukan bagi peraturan perundang-undangan lainnya.

Menurut Latif (2012), Sebagai negara hukum, maka setiap kegiatan negara yang diatur dengan peraturan perundang-undangan harus ditujukan kepada upaya peningkatan kesejahteraan rakyat. Negara hukum Indonesia tidak sama dengan negara hukum pada negara-negara yang lain, karena negara hukum Indonesia memiliki karakter sendiri sebagaimana diamanatkan dalam Pancasila (Asshiddiqie, 2014).

Negara hukum Pancasila juga disebut sebagai negara hukum kesejahteraan, hal ini karena tujuan negara Indonesia adalah memberikan kesejahteraan bagi seluruh rakyat Indonesia sebagaimana tercantum dalam Pembukaan UUD, demikian pula dalam sila kelima dari Pancasila, yaitu Keadilan Sosial Bagi Seluruh Rakyat Indonesia.

Berkenaan dengan itu, Jimly Asshiddiqy menegaskan bahwa UUD tidak hanya berfungsi sebagai konstitusi politik, melainkan juga sebagai konstitusi ekonomi. Persoalan perekonomian di dalam UUD diatur dalam satu bab dengan kesejahteraan. Kesejahteraan menjadi tujuan dari kegiatan perekonomian di Indonesia (Ali, 2011).

Berdasarkan UUD, kegiatan perekonomian di Indonesia tidak hanya diselenggarakan oleh pribadi dan badan hukum swasta saja, melainkan juga diselenggarakan oleh negara dan daerah (Swasono, 1993). Konsepsi seperti ini diatur dalam Pasal 33 ayat (2) yang menegaskan bahwa cabang-cabang produksi yang penting bagi negara dan yang menguasai hajat hidup orang banyak dikuasai oleh negara. Demikian pula, dalam ayat (3) ditegaskan pula, bahwa bumi dan air dan kekayaan alam yang terkandung di dalamnya dikuasai oleh negara dan dipergunakan untuk sebesarbesarnya bagi kemakmuran rakyat.

Secara struktural, ketentuan tersebut mempertegaskan bahwa kegiatan perekonomian yang terkait dengan kebutuhan masyarakat yang fundamental dan strategis tidak diserahkan kepada swasta, melainkan tetap menjadi kewajiban pemerintah, baik itu pemerintah pusat, pemerintah provinsi maupun pemerintah kabupaten/kota. Salah satu kebutuhan yang fundamental bagi masyarakat yang masih dipertahankan untuk dikelola sepenuhnya oleh pemerintah sebagai kewajiban konstitusional adalah pelayanan air minum. Dalam hal ini, dikelola oleh Pemerintah Provinsi atau Pemerintah Kabupaten/Kota dengan membentuk Perusahaan Daerah Air Minum.

Pemerintah daerah bertindak sebagai pemilik modal terhadap PDAM tersebut. Konsekwensinya, pemerintah daerah wajib menyertakan modal pada perusahaan tersebut, baik dalam bentuk uang maupun barang sebagaimana diatur dalam peraturan perundang-undangan.

Penyertaan modal ini harus mengindahkan ketentuan yang berlaku. Perundangundangan telah mengatur tentang tata cara penyertaan modal itu, dalam rangka untuk menghindari terjadinya kerugian daerah akibat penyertaan modal itu. Di sisi lain, penyertaan modal daerah kepada PDAM sering dipersoalkan dari segi bisnis, karena 
banyak PDAM tidak memberikan pemasukan bagi pendapatan asli daerah, dan bahkan banyak PDAM yang merugi.

\section{METODOLOGI PENELITIAN}

Metode penelitian yang digunakan dalam kajian ini adalah penelitian normatif, hal ini karena kajian dari tulisan ini tidaklah mengkaji praktek pengadminsitrasian sebagai perilaku dari masyarakat. Penelitian ini hanya mengkaji teori-teori dan praktek pengadministrasian negara yang terdapat dalam bentuk dokumentasi hukum. Oleh karena itu, penelitian ini disebut pula kajian kepustakaan, karena bahan-bahan yang digunakan kajian ini secara ringkas adalah kajian literatur dan kajian dokumentasi hukum, yaitu peraturan perundang-undangan, baik tingkat nasional maupun daerah.

\section{PEMBAHASAN}

\section{Penyediaan Air Minum oleh PDAM Sebagai Pelayanan Publik}

Air minum merupakan kebutuhan utama bagi manusia, tanpa air minum yang bersih, dapat menyebabkan timbul berbagai penyakit. Air minum yang bersih dan sehat serta aman untuk dikonsumsi telah menjadi isu daerah, nasional dan bahkan internasional. Oleh karena itu, tidak heran Perserikatan Bangsa-Bangsa melalui World Health Organization (WHO) dan Unicef telah melakukan berbagai kegiatan yang berkenaan dengan ketersedian air bersih ini.

Kesulitan terhadap air bersih masih menjadi persoalan sehari-hari, karena masih banyak penduduk yang belum mendapatkan air bersih sebagaimana diharapkan. Pelayanan air minum oleh PDAM masih terbatas pada wilayah perkotaan saja, dan bahkan pada wilayah perkotaanpun belum sepenuhnya dapat dijangkau oleh PDAM. Walaupun pelayanan penyediaan air minum oleh PDAM telah menjangkau rumahrumah masyarakat, namun air sering kali tidak mengalir, bahkan hanya menjadi simbol saja dari kehadiran PDAM.

Dengan demikian, masyarakat desa masih sangat sedikit dapat terlayani oleh PDAM. Bagi masyarakat yang tidak terjangkau oleh PDAM, maka ketersedian air berasal dari sumur, sungai, ataupun mengebor tanah atau yang sering disebut sumur bor. Ketika musim kemarau tiba, maka sumur dan sungai mengering, ini telah menimbulkan banyak masalah bagi masyarakat. oleh karena itu, banyak pemberitaan yang menyebutkan bahwa masyarakat terpaksa harus rela antri panjang dan memakan waktu berjam-jamuntuk mendapatkan air bersih yang disuplai dengan mobil tangki oleh pemerintah daerah atau bahkan ada yang terpaksa harus mencari sumber air meskipun jarak tempuh yang sangat jauh. Untuk itu, maka keberadaan PDAM tetap harus eksis dalam kerangka mensejahterakan rakyat.

Masyarakat yang memiliki penghasilan yang cukup permasalahan air minum, tetap saja jadi masalah. Meskipun sudah tersedia air minum kemasan namun harganya juga masih mahal, selain ditemukan permasalahan lain, misalnya banyak air minum kemasan yang tidak memenuhi syarata kesehatan.

Di negara-negara maju, ketersediaan air minum tidak lagi menjadi permasalahan, karena air bersih sudah tersedia dengan cukup. Bahkan pemerintah telah menyediakan air minum yang dapat langsung didapatkan dari kran air di setiap sudut kota. Tidak jauh dari negara kita, negara tetangga misalnya Singapore. Di negara ini di setiap sudut 
kota, terutama ditempat publik, dengan begitu mudah dapat diperoleh kran air minum yang sehat untuk langsung diminum.

\section{Pembentukan Perusahaan Daerah}

Pelayanan publik yang diselenggarakan oleh pemerintah daerah di Indonesia dalam prakteknya dilaksanakan dalam tiga model, yaitu pertama, sendiri oleh pemerintah daerah melalui lembaga-lembaga daerah yang disebut dengan Satuan Kerja Perangkat Daerah (SKPD), kedua, dikotrakkan kepada pihak swasta untuk melaksanakannya berdasarkan perjanjian pembrongan (sistem proyek), dan yang ketiga, adalah diselenggarakan oleh perusahaan daerah.

Kewajiban penyedian air minum oleh daerah kepada rakyatnya dipilih pola yang ketiga, yaitu membentuk PDAM sebagai lembaga pelaksananya. Daerah membentuk PDAM berdasarkan ketentuan perundang-undangan. Undang-undang tentang Perusahaan Daerah, yaitu Undang-Undang Nomor 5 Tahun 1962, namun undangundang ini telah dicabut dengan Undang-Undang Nomor 23 Tahun 2014 Tentang Pemerintahan Daerah (UU Pemda).

Ketentuan Pasal 189 ayat (1) Undang-Undang Nomor 11 Tahun 2006 tentang Pemerintahan Aceh, juga mengatur tentang penyertaan modal daerah, dimana ditegaskan bahwa daerah dapat melakukan penyertaan modal/kerja sama pada/dengan Badan Usaha Milik Negara/Daerah dan/atau badan usaha milik swasta atas dasar prinsip saling menguntungkan.

Demikian pula, dalam Undang-Undang Nomor 1 Tahun 2004 Tentang Keuangan Negara. Ketentuan Pasal 41 ayat (5) Undang-Undang Nomor 1 Tahun 2004 tentang Keuangan Negara, menegaskan bahwa penyertaan modal pemerintah daerah pada perusahaan daerah ditetapkan dengan peraturan daerah. Sebagaimana pelaksanaan undang-undang ini, ketentuan Pasal 75 Peraturan Pemerintah Nomor 58 Tahun 2005 tentang Pengelolaan Keuangan Daerah juga secara tegas menyatakan bahwa penyertaan modal pemerintah daerah dapat dilaksanakan apabila jumlah yang akan disertakan dalam tahun anggaran berkenaan telah ditetapkan dalam peraturan daerah tentang penyertaan modal daerah yang berkenaan.

Berikutnya, Undang-Undang Nomor 23 Tahun 2014 Tentang Pemerintahan Daerah. Menurut undang-undang ini, perusahaan daerah sebagaimana dimaksud dalam UndangUndang Nomor 5 Tahun 1962 tentang Perusahaan Daerah disebut dengan Perusahaan Umum Daerah (PERUMDA). Ketentuan Pasal 332 UU Pemda menegaskan bahwa sumber modal PERUMDA terdiri atas:

a. penyertaan modal Daerah;

b. pinjaman;

c. hibah; dan

d. sumber modal lainnya.

Penyertaan modal Daerah dapat dilakukan untuk penambahan modal PERUMDA. Penyertaan modal Daerah dapat berupa uang dan barang milik Daerah. Ketika penyertaan modal dilakukan dalam bentuk barang, maka barang milik Daerah dinilai sesuai nilai riil pada saat barang milik Daerah akan dijadikan penyertaan modal.

Menurut UU Pemda, Perusahaan Daerah ini disebut dengan Perusahaan Umum Daerah (PERUMDA). Perusahaan ini modalnya secara keseluruhan adalah milik 
daerah, tidak dibenarkan pemerintah pusat atau pihak swasta menjadi bagian dari kepemilikannya.

Pembentukan PERUMDA ini memerlukan tertib administrasinya, dimana pembentukannya harus dengan Peraturan Daerah dari daerah yang menjadi pemiliknya. Oleh karena itu, pembentukan PERUMDA harus melibatkan Dewan Perwakilan Rakyat Daerah yang bersangkutan.

Pelibatan ini menjadi kewajiban perundang-undangan sebagaimana dimaksudkan dalam Undang-Undang Nomor 12 Tahun 2011 Tentang Pembentukan Perundangundangan. Undang-undang ini menegaskan bahwa sebuah Perda dibentuk atas persetujuan bersama antara Bupati/Walikota dengan Dewan Perwakilan Rakyat Daerah.

Sebagai badan hukum, PERUMDA harus memiliki struktur organisasi. Secara teoritis, sebuah badan hukum harus memenuhi empat syarat, yaitu:

1. Kekayaan yang terpisah dengan kekayaan pemiliknya;

2. Mempunyai tujuan tertentu;

3. Mempunyai kepentingan tertentu; dan

4. Adanya organisasi yang teratur.

Struktur organisasi wajib ada dalam PERUMDA sebagai badan hukum. Struktur organisasi PERUMDA terdiri Gubernur/Bupati/Walikota sebagai pemilik, direksi dan dewan pengawas. Jumlah jajaran direksi dan pengawas itu, berdasarkan peraturan Menteri Dalam Negeri ditentukan berdasarkan jumlah pelanggan dari PDAM yang bersangkutan.

Keberadaan struktur organisasi tersebut adalah untuk menjalankan fungsi dari administrasi negara terhadap lembaga daerah. Kegiatan sehari-hari dari PDAM dijalankan oleh jajaran direksi, sedangkan dewan pengawas berfungsi melakukan pengawasan atas kinerja PDAM sekaligus memberikan nasihat dan masukan kepada direksi dalam menjalankan adminsitrasi PDAM. Dewan pengawas tidak dibenarkan untuk ikut campur dalam pengurusan PDAM. Hasil dari pengawasan, dewan pengawas wajib memberikan laporan kepada Kepala Daerah untuk ditindaklanjuti.

\section{Pengadminstrasian Penyertaan Modal}

Perusahaan Daerah Air Mimun juga sebagai badan hukum yaang dimiliki, memberikan kewajiban bagi daerah untuk menyertakan modal ke PDAM. Adanya penyertaan modal ini adalah sebagai konsekuensi dari ciri-ciri badan hukum yang memiliki kekayaan sendiri, terpisah dengan kekayaan pemilik (Admosudirjo, 1994).

Penyertaan modal ini merupakan pemisahan dari kekayaan daerah untuk ditempatkan menjadi kekayaan dari PDAM.Kekayaan daerah yang dipisahkan tersebut dapat berupa uang dan/atau barang. Oleh karena itu, penyertaan modal itu menurut peraturan perundang-undangan, dapat dalam bentuk uang dan/atau barang.

Penyertaan modal oleh pemerintah daerah ke dalam perusahaan daerah adalah suatu investasi, dimana menurut Pasal 41 ayat (1) Undang-Undang No. 1 Tahun 2004 Tentang Perbendaharaan Negara yang menyebutkan pemerintah daerah dapat melakukan investasi jangka panjang untuk memperoleh manfaat ekonomi, sosial, dan/atau manfaat lainnya. Penyertaan modal pemerintah daerah pada perusahaan negara/daerah/swasta, menurut ayat (5) pasal ini ditetapkan dengan peraturan daerah.

Menurut Pasal 28 ayat (3) huruf b Peraturan Pemerintah Nomor 58 Tahun 2005 Tentang Pengelolaan Keuangan Daerah ditegaskan penyertaan modal ini sebagai 
pembiayaan dari pemerintah daerah. Oleh karena itu penyertaan modal oleh pemerintah daerah kepada PDAM, menurut Pasal 1 angka 5 Peraturan Menteri Dalam Negeri Nomor 48 Tahun 2016 disebutkan sebagai salah satu bentuk investasi dari pemerintah daerah.

Secara legal formal, penyertaan modal harus diawali dengan suatu studi kelayakan investasi terhadap rencana penyertaan modal. Apabila menurut studi ini, investasi itu menguntungkan, maka dilanjutkan dengan pembentukan peraturan daerah tentang penyertaan modal kepada perusahaan yang dituju, dan berikutnya menempatkan pembiayaan ini dalam anggaran pendapatan dan belanja daerah. Namun untuk kasus tertentu studi kelayakan dapat tidak dilakukan (Permen Dalam Negeri No. 48 Tahun 2016), apabila penyertaan modal itu merupakan perintah dari perundang-undangan dalam rangka melaksanakan tugas negara guna mensejahterakan rakyat.

Untuk melaksanakan pelayanan air minum, PDAM selain bersumber pada penyertaan modal, juga mendapatkan dana pinjaman dari Pemerintah Pusat melalui Kementrian Keuangan Republik Indonesia. Contohnya adalah pemerintah pusat telah memberikan pinjaman kepada 107 PDAM diseluruh Indonesia sebesar Rp. 3,9 triliun.

Pinjaman tersebut dilakukan oleh Pemerintah Pusat dalam rangka penyehatan keuangan dari PDAM di seluruh Indonesia, yang karena berbagai faktor membutuhkan bantuan untuk perbaikan insfrastruktur dari pelayanan air minum. Pola ini diambil, karena Pemerintah Pusat dilarang untuk menjadi bagian dari kepemilikan PDAM. Hal ini dilakukan, karena menurut Pasal 234 Undang-Undang Nomor 23 Tahun 2014 tentang Pemerintahan Daerah, maka pemerintah pusat tidak boleh melakukan penyertaan modal pada perusahaan daerah.

Pinjaman Rp. 3,9 triliun tersebut, dalam tahun anggaran 2016 ini tidak lagi dicatat oleh pemerintah pusat sebagai pinjaman, melainkan dana sebesar itu telah dicatat sebagai hibah kepada Pemerintah Daerah sebagai pemilik dari PDAM yang diberikan pinjaman.

Secara teoritis, berdasarkan kesepakatan dari kreditur dan debitur dapat dirubah menjadi penyertaan modal. Namun karena adanya larangan kepemilikan PDAM oleh pemerintah pusat, maka pinjaman modal itu dialihkan menjadi hibah kepada pemerintah daerah.

Perubahan pencatatan itu dilakukan berdasarkan surat dari Kementrian Keuangan Nomor S-36/MK.7/2016 tanggal 23 Agustus 2016 perihal penetapan pemberian hibah daerah dalam bentuk non kas kepada pemerintah daerah dalam rangka penyelesaian piutang negara pada PDAM.Dana sebesar pinjman pemerintah pusat tetap berada pada PDAM, dengan merubah menjadi penyertaan modal dari pemerintah daerah dari sebesar dana hibah pemerintah pusat. Perubahan skema pinjaman dari Pemerintah pusat, dilakukan untuk menyehatkan keuangan PDAM di seluruh Indonesia.

Hibah dari Pemerintah Pusat kepada Pemerintah Daerahdengan tujuan penyertaan modal ini berdasarkan Pasal 3 Peraturan Menteri Dalam Negeri Nomor 48 Tahun 2016 tentang Pedoman Penerimaan Hibah dari Pemerintah Pusat kepada Pemerintah Daerah, dan Penyertaan Modal, Pemerintah Daerah Kepada Perusahaan Daerah Air Minum, Dalam Rangka Penyelesaian Hutang Perusahaan Daerah Air Minum kepada Pemerintah Pusat Secara Non Kas.

Penyertaan modal skema ini menjadi menarik, karena penyertaan modal ini tidak disertai dengan penyerahan kekayaan daerah dalam bentuk kas kepada PDAM, 
melainkan dalam bentuk non kas. Sehingga sacara sepintas, akan disebut sebagai penyertaan modal secara fiktif. Pemahaman seperti ini adalah salah, karena pada dasarnya kekayaan dalam bentuk kas sudah diterima oleh PDAM jauh sebelum penyertaan modal itu, yaitu secara kas dihitung ketika pinjaman dari pemerintah pusat itu diterima.

Dengan demikian, hibah dari pemerintah pusat dari pemerintah pusat kepada pemerintah daerah juga dalam bentuk non kas. Hibah non kas yang diterima oleh Pemerintah Daerah sebagai pemilik PDAM, berdasarkan Pasal 5 Peraturan Menteri Dalam Negeri tersebut, harus dianggarkan dalam Anggaran Pendapatan dan Belanja Daerah yang bersangkutan untuk tahun anggaran 2016 atau perubahannya.

Berdasarkan ketentuan penyertaan modal daerah harus dengan peraturan daerah, maka bagi daerah yang menjadi pemilik PDAM tersebut, harus mengundangkan Peraturan Daerah masing-masing. Apabila PERDA ini tidak ada, maka konsekuensinya hibah itu tidak jadi diberikan oleh Pemerintah Pusat, dan sebaliknya Pemerintah Pusat masih mencatat dana yang diterima oleh PDAM sebagai piutangnya padaPDAM.

Secara tertib adminstrasi keuangan daerah, berdasarkan perda penyertaan modal tersebut, maka nilai penyertaan modal non kas ini harus dicantumkan dalam APBK tahun berjalan. Hal ini untuk menjaga akuntabilitas dari penggunaan anggaran daerah.

\section{SIMPULAN}

Penyertaan modal oleh pemerintah daerah dalam perusahaan daerah adalah konsekwensi dari kewajiban konstitusional.Bagi rakyat, air minum merupakan kebutuhan pokok rakyat yang harus tetap menjadi cabang produksi penting yang harus dikelola negara. Penyertaan modal daerah tidak hanya melihat pada keuntungan daerah, melainkan lebih dari itu, yaitu untuk pelayanan publik. Sebagai tertib adminstrasi keuntungan negara, maka penyertaan modal harus dilakukan menurut kaedah-kaedah tertentu. adanya tertib administrasi ini akan dapat menghindari penyertaan modal yang dapat merugikan keuangan negara, dalam hal ini keuangan daerah.

\section{REFERENSI}

Chidir, Ali. 2011. Badan Hukum, Alumni, Bandung.

Hamud M. Balfas. 2006. Hukum Pasar Modal Indonesia. Jakarta: Tatanusa.

Asshiddiqie, Jimly. 2010. Konstitusi Ekonomi. Jakarta: Kompas Penerbit Buku.

Juraid, Abdul L. 2012. Manusia, Filsafat dan Sejarah. Jakarta: Bumi Aksara.

Kaelan. 2013. Negara Kebangsaan Pancasila. Paradigma, Yogyakarta.

Satrio, J. 1999. Hukum Pribadi, Bagian I Persoon Alamiah, Bandung: Citra Aditya Bakti.

Sri Edi Swasono. 1993. Demokrasi Ekonomi: Keterkaitan Usaha Partisipatif vs Konsentrasi Ekonomi, Pancasila sebagai ideology dalam berbagai Bidang Kehidupan Bermasyarakat, Berbangsa dan Bernegara, Karya Anda,Surabaya. 